\title{
Academics Telecommuting in Open and Distance Education Universities: Issues, challenges, and opportunities
}

\author{
Cheuk Fan Ng \\ Athabasca University - Canada's Open University
}

\begin{abstract}
Research in distance and online education has focused on how to improve students' learning and support services. Faculty satisfaction, as one of the five pillars in Sloan-Consortium's quality framework for online education, has received less attention in research. Besides online teaching, little research has examined the experiences of academics working in institutions where the faculty is dispersed geographically. Outside the academy, teleworking or telecommuting has become quite popular in recent years. Most research to-date has been conducted in information technology-related corporations and government departments, but hardly any in post-secondary educational institutions. Drawing on a literature review of research in telecommuting or teleworking, this paper discusses the potential benefits and drawbacks of telecommuting for academics and their families, and the potential opportunities for - and challenges faced - by their distance and online education institutions.
\end{abstract}

Keywords: telecommuting; telework; distance education; online education; faculty; work conditions; academia

\section{Introduction}

Distance education has emerged as an important form of education in the last few decades. In recent years, the offering of online courses and programmes has become increasingly popular not only in distance education institutions, but in traditional universities as well (Wheeler, 2002). The Sloan-Consortium proposed a five-pillar quality framework for online education in colleges: 1.) learning effectiveness; 2.) cost effectiveness; 3.) access; 4.) faculty satisfaction; and 5.) student satisfaction (Moore, 2002). Within this quality framework, distance education universities have been striving to enhance learning effectiveness and student satisfaction. Academic journals such as the International Review of Research in Open and Distance Learning and the Journal of Distance Education devote to the academic exchanges of ideas and research on how to enhance learning effectiveness for students. Fewer exchanges, however, have been about faculty satisfaction.

With respect to learning effectiveness, several theoretical models have been proposed to explain the lack of persistence or high attribution among students in higher education in general, and in open and distance learning in particular. These models focused on the fit between student and institution and on environmental variables. Tinto's student integration model (1975) theorized that successful persistence of traditional on-campus students was determined by both student characteristics and experiences prior to college, and their experiences while at college. The 
student integration process, which comprised both academic and social experiences in college, was essential for student success. Bean and Metzner's student attrition model (1985), which was more applicable to non-traditional students who were commuters, emphasized the influences of factors outside the institution (e.g., family support and finance). More recently, Rovai (2003) synthesized these two models with research on the skills required and the needs of students in online and distance education (Workman and Stenard, 1996) into a composite model for student success in online and distance learning. Research has indicated that internal factors such as students' personality (Irani, Telg, Scherler, and Harrington, 2003), previous academic performance, ability for self-directed learning, and communication patterns, and external factors such as family support and finances, are related to student success and persistence in distance learning (Rovai, 2003).

With respect to experiences of learning at a distance, some research suggested a sense of isolation for many students (Wheeler, 2002) and a lower sense of social community at both the classroom and school level (Rovai, Wighting, and Liu, 2005).

Compared with learning effectiveness and student satisfaction, much less is known about faculty experiences and satisfaction in open and distance education institutions. If students' quality of learning is intricately tied to faculty's teaching effectiveness and research productivity, then it is crucial to understand and improve its faculty members' work environment. Research in higher education in general has examined the work conditions and the institutional climate that may affect academics' productivity and general well-being such as gender, ethnic diversity, and professional development (Gappa, Austin, and Trice, 2005). Few has examined the working conditions of academics at distance education institutions, even though some research has examined the faculty's experiences in online teaching in traditional institutions (Ryan, Carlton, and Ali, 2004; Shea, Pickett, and Li, 2005). This is no surprise as the Sloan-Consortium framework limits the scope of faculty satisfaction to "teaching online and for conducting research about improving teaching online” (Moore, 2002). Nothing is said about the faculty's role in disciplinary and inter-disciplinary research or its role in institutional governance and services provided to the institution and the community at large. An exception is Yick, Patrick, and Costin's study (2005) conducted in a for-profit online university, in which they examined online faculty's perception of online teaching, credibility, role of research and tenure in distance education by academic colleagues in traditional institutions.

Hardly any research exists that examines the experiences of academics working at a distance. In a chapter entitled The Professor as Teleworker, Guthrie, Olson, and Schaeffer (1998) conceptualized the distribution of faculty and students in higher education along the centralization-decentralization dimension. In such a framework, both faculty and students at a traditional university were in a centralized location. Other possibilities that existed in distance education institutions included: one where the faculty was centralized and students were dispersed; one where the faculty was dispersed and students were centralized; and one where both faculty and students were dispersed. It is not known, however, to what extent these three studentfaculty dispersion models are used in open and distance education institutions. Like our students studying at a distance, many academics in these institutions are also working at a distance. What are the experiences of these academics? What are the issues, challenges, and opportunities for academics who telework or telecommute? What are the issues, challenges, and opportunities that face their families and their institutions?

Outside the academy, with rapid advances in information and telecommunication technologies, teleworking or telecommuting has become quite popular in recent years. Most research to-date that examines teleworking or telecommunicating has been conducted in information technologyrelated corporations in the private sector and government departments in the public sector. Little 
research has been conducted in post-secondary educational institutions, even though it is common knowledge that professors and instructors "telecommute" some of the time.

Drawing on a literature review of research and practices of telecommuting as an alternative work arrangement outside the academy, this paper discusses some of the major non-technological issues, potential benefits and drawbacks of telecommuting for telecommuting academics and their families, and potential opportunities for and challenges faced by their institutions. Though critically important, a detailed examination of the technologies and the role that information and communication technologies play in enhancing the effectiveness and efficiency of a dispersed faculty work environment is beyond the scope of this paper. The issues discussed in this paper are confined to those relevant to full-time academics teaching in open, distance, and online education institutions as core faculty and who telecommute. Some open and distance education institutions such as Athabasca University and Capella University for example (Yick et al., 2005) incorporate both full-time, core faculty, and a contingent group of part-time faculty located in different regions (variously known as academic coaches, tutors, mentors, or adjunct faculty); however, it is not known how common such practice is. As full-time and part-time faculty have quite different work conditions and experiences at traditional, campus-based institutions (Mullens, 2001), it is important to examine the experiences of part-time faculty at open and distance institutions, as well in future research.

\section{Literature Review of Research in Telecommuting outside the Academy}

\section{What is 'telecommuting' or 'telework?'}

With rapid advances in information and telecommunication technologies, teleworking or telecommuting has become quite popular in recent years. Nilles (1975) first used the term 'telecommuting' to refer to working away from the conventional office and communicating with it by way of telecommunications or computer-based technology.

Although teleworking and telecommuting are often used interchangeably in the popular and academic literature, some authors have distinguished between the two terms. Pinsonneault and Boisvert (1996) suggested that telecommuting had three principal components: 1.) utilization of information technology (IT); 2.) link with an organization; and 3.) de-localization of work. Delocalization of work takes four main forms: 1.) telecommuting from home; 2.) satellite offices; 3.) neighbourhood work centres; and 4.) mobile work. Satellite offices are small organizational facilities located close to residential areas where a telecommunication link with the headquarters is permanently maintained. Neighbourhood work centres are private information centres that are shared by employees from different organizations. Not limited to any specific physical location, mobile work is performed anywhere where workers can communicate with the office as necessary (e.g., in a hotel room) (Kurland and Bailey, 1999; Pinsonneault and Boisvert, 1996). These alternative work forms together constitute "teleworking” (Kurland and Bailey, 1999).

\section{Who telecommute or telework?}

According to Bailey and Kurland's (2002) comprehensive review, researchers have been unable to clearly describe the demographics of teleworkers. Many studies have been designed to identify the traits of employees who could telework and the factors that predict who will telework. The job traits often identified included an employee's ability to control work pace and little need for face-to-face interaction. Knowledge workers and information workers were considered prime candidates for teleworking. It was the perceptions of job suitability, however, that may better predict who would telework. Bailey and Kurland (2002) cautioned that job suitability was often confounded with issues of status and power. Although some clerical and professional positions 
may both be suitable for telework, clerical workers may face greater opposition to their requests to work at home from management (Olson and Primps, 1984; Treasury Board of Canada Secretariat, 1996). Research to-date suggests teleworkers come from a predominantly male professional segment and a largely female clerical segment. Manager's willingness appears to be most predictive of who actually will telework (Bailey and Kurland, 2002).

\section{Frequency of telecommuting}

Research has shown that telecommuters generally work part-time at home, going to corporate offices for meetings and to confer with colleagues (Gurstein, 1995). Karnowski and White (2002) reported that telecommuters worked in the corporate office two days a week on average, with a range between half-a-day and four days. Similarly, teleworkers in Canadian federal government departments who participated in a pilot programme telecommuted three days a week on average (Treasury Board of Canada Secretariat, 1996).

\section{Methodological issues of research in telecommuting}

According to academic reviews published in the last few years (Bailey and Kurland, 2002; McCloskey and Igbaria, 1998), research has relied heavily on general surveys designed to simply establish the extent of telecommuting participation and on case studies of pilot programmes in which employees volunteered to be included in a formal programme or in which informal arrangements were made. The number of participants in many of these programmes was small. Early studies sought to describe the practice of such work arrangements. More recent research has included control groups or has surveyed both telecommuters and non-telecommuters, and their supervisors (Cooper and Kurland, 2002; Treasury Board of Canada Secretariat, 1996), indicating that the vigour of research is improving (Bailey and Kurland, 2002). The number of studies that tested explicit hypotheses or building models has grown steadily since the 1990s (Bailey and Kurland, 2002; McCloskey and Igbaria, 1998).

The lack of a clear, accepted definition is one of the weaknesses of research, making comparison across studies difficult (Ellison, 1999; Pinsonneault and Boisvert, 1996). Differences in definitions have revolved around the issues of use of technology, location, employment relationships, and employment structure. Should home-based self-employed individuals be included in the definition of telecommuters? Should only organizational employees who spend part or all of their work time at a non-traditional site instead of the traditional work place be considered as telecommuters? Should organizational staff working remotely at other organizations, branch, or subsidiary facilities within the organization, or satellite and neighbourhood work centres, be counted as telecommuters? Or should telecommuters be limited to those working alone at home? Should full-time and part-time employees who telecommute be studied separately as they may have different needs and motivation? (McCloskey and Igbaria, 1998)

Most research in telecommuting has focused on the telecommuter and, occasionally, on the telecommuter's supervisor and non-telecommuters. Few studies have examined the impact of telework on the organization as a whole, or even on smaller work groups. Research has been conducted mostly in information technology-related corporations and government departments (Bailey and Kurland, 2002).

The following section reviews research that addresses some of the potential benefits and drawbacks of telecommuting, and discusses some of the issues relevant to academics telecommuting from home, their families, and their institution. 


\section{Issues for the Academic}

\section{Balance between work and family}

Greater flexibility in personal and family activities scheduling is often cited as one major reason for telecommuting from home (Pinsonneault and Boisvert, 1996). According to Bailey and Kurland's (2002) review, women are more likely than men to see family benefits as a reason for telework. A few studies supported the claim that telecommuting has helped employees to balance work and family responsibilities, particularly among dual-career couples. Other studies showed that couples with no children were more interested in telework than were couples with one or two children. For example, compared with non-teleworkers, teleworkers in the Treasury Board Pilot Programme reported a significant improvement in their balance between work life and personal life and in the flexibility to coordinate work and personal responsibilities (Treasury Board of Canada Secretariat, 1996). Employees working in home offices reported more positive views about family and personal life (i.e., management of home chores, eldercare, and childcare), than employees working in a traditional office (Hill, Ferris, and Martinson, 2003).

Home-based telecommuting, however, does not mean there is no need for childcare. Research has shown that multiple roles are likely to cause conflict, thus increasing stress rather than lowering stress (Bailey and Kurland, 2002; Gurstein, 1995). Some studies reported that teleworkers with small children had difficulty balancing childcare and work responsibilities (Olson, and Primps, 1984; McCloskey and Igbaria, 1998). Role conflict between work and family can affect telecommuting outcomes (Duxbury, Higgins, and Neufeld, 1998). For these reasons, some telecommuting programmes (Alberta Government, 1999; Treasury Board of Canada Secretariat, 1996) required that telecommuters have separate childcare or eldercare arrangements. Intrusions from family, neighbours, and friends were reported as major problems with working at home (Gurstein, 1995), thus lowering satisfaction with telecommuting (Hartman, Stoner, and Arora, 1991).

\section{Increased productivity and job satisfaction}

Another often cited potential benefit of telecommuting is increased productivity and work quality. Several factors could explain the potential increase in productivity: less distraction and fewer interruptions at home; a work environment better suited to the needs of the particular employee and the particular task; the ability for the employee to work during the most productive part of the day; and time saved from commuting (Pinsonneault and Boisvert, 1996).

Even though accounts of increased productivity among teleworkers are common, these accounts are based on self-report data. Few empirical studies have measured productivity increase directly and objectively (Pinsonneault and Boisvert, 1996), except using such easily measured variables as absenteeism (McCloskey and Igbaria, 1998). As most teleworkers in pilot programmes requested to work at home, their perceptions and claims may be biased. Interestingly enough, many of the teleworkers in these studies (Gurstein 1995; Treasury Board of Canada Secretariat, 1996) reported longer working hours. Bailey and Kurland (2002) suggested the possibility that increased productivity may have been confounded with longer hours at work. The lack of physical separation between the work and non-work domains may promote tendencies towards working longer hours for those employees who are highly involved in their jobs (Olson and Primps, 1984). There has been some evidence, however, for an association between telecommuting and higher productivity; for example, the telecommuters' supervisors in the Treasury Board Pilot Programme agreed with the telecommuters that productivity had increased, even though to a lesser extent (Treasury Board of Canada Secretariat, 1996). 
Increased job satisfaction is another often cited potential benefit. Bailey and Kurland (2002) concluded that there was little clear evidence of an increase in overall job satisfaction among teleworkers in the studies they reviewed. Telecommuters did report, however, that they enjoyed the freedom and flexibility of working at home. For example, the telecommuters in the Treasury Board Pilot Programme (Treasury Board of Canada Secretariat, 1996) reported greater control over their work environment, less interruption in work, and less stress. Compared with employees working in a traditional office, those working in a home office felt that telework had enhanced their job performance, job motivation, and job retention (Hill, Ferris, and Martinson, 2003).

Telecommuting frequency appears to be a significant factor in individual and organizational outcomes (McCloskey and Igbaria, 1998). For example, Hartman, Stoner, and Arora (1991) reported that as the telecommuters in their study spent a higher proportion of their total work time in telecommuting, their perceptions of overall productivity at home declined. Golden and Veiga's study of technical professionals (2005) showed a curvilinear relationship between extent of telecommuting and job satisfaction, with the highest satisfaction level at about 15 hours per week.

In short, the research has showed no clear evidence that telecommuting is associated with higher productivity or higher overall job satisfaction. If telecommuting has real, measurable increase in productivity, then it is good for employees and their organization. If higher productivity results from longer working hours however, then it is likely to harm the employees and their families. Considering that many academics are high achievers and are fully committed to their work, the blurring of the boundaries between work and family lives can be problematic. The lack of balance between work and personal life was a main source of stress reported by new faculty members in traditional institutions of higher learning (Sorcinelli, 1994).

\section{Work environment at home}

Some cited a more comfortable work environment as an advantage of home-based telecommuting (Kurland and Bailey, 1999). What are home workspaces like however? In Karnowski and White's (2002) survey of facility managers, 87 respondents reported that 38 percent of their commuters' off-site work areas were shared space, and only 35 percent were separate, home offices. In a Canada-wide survey, Gurstein (1995) reported that 92 percent of their respondents who were teleworkers in the public sector, crown corporations, or private sector had a designated workspace at home, but two-thirds had shared space. The most frequently reported location was the basement (30 percent), followed by a spare room (24 percent), and the main floor of the house (18 percent). The median office size was 13.4 sq. $\mathrm{m}$.

For many home-based workers, their work environment at home is far from ideal. In Gurstein's (1995) survey, the ideal type of workspace included a separate room with natural lighting and ventilation, visual and acoustical privacy, and adequate storage and power outlets. Many survey respondents, however, indicated that they had to modify their home to make it suitable for work. The major problems included lack of storage space (50 percent), workspace too small (45 percent), poor lighting (35 percent), and too few telephone lines (30 percent). Safety and health concerns must be addressed to ensure the workspace at home is hazard-free and meet minimum ergonomic standards (Gurstein, 1995; Rodstein and Watters, 2001).

A related issue is the costs in equipping and running the home office. Typically, employers paid for additional data connection points (Rodstein and Watters, 2001) and provided off-site computing and telecommunications equipment, but less frequently, office equipment (Karnowski and White, 2002; Treasury Board of Canada Secretariat, 1996).

Inadequate space and equipment can affect the productivity of telecommuting academics. Lack of storage space is likely a bigger problem for academics than managers and professionals surveyed 
Chuek Fan Ng, Academics Telecommuting in Open and Distance Education Universities

in previous research, as academics tend to accumulate books and reports in addition to needing space for computer and telecommunication equipment. Academics in some disciplines must find alternative research space outside their homes that conforms to strict safety and security standards. Unless there is appropriate insurance coverage, telecommuting academics cannot have research assistants working at their homes or meet with colleagues and visitors at their homes.

\section{Professional and social isolation}

As with students (Wheeler, 2002), working alone at home can be an isolating experience. Professional and social isolation is a commonly cited obstacle to telecommuting. Studies have examined the attitudes of both employees and managers, and have compared telecommuters' and non-telecommuters' perception of various aspects of their work, such as visibility (McCloskey and Igbaria, 1998). One fear employees expressed was that being out-of-sight would limit opportunities for promotion and organizational rewards (Cooper and Kurland, 2002). Similarly, telecommuters in another study reported that career opportunities, sense of belonging to organization, and interaction with colleagues on work-related matters, were the negative changes related to personal and professional life (Treasury Board of Canada Secretariat, 1996). Note that because many of the larger studies in telecommuting examined only the perceived impacts of telecommuting rather than actual impacts, there is yet any empirical evidence to substantiate the claims of actual impact on career advancement (Pinsonneault and Boisvert, 1996). Nevertheless, perceived professional isolation appears to be inextricably linked to employee development activities. In a qualitative study of telecommuters, their supervisors, and non-telecommuters from two high-technology firms and two city government agencies (Cooper and Kurland, 2002), telecommuters perceived that they did not have the same degree of access to informal development opportunities regarding: 1.) interpersonal networking with others in the organization; 2.) informal learning; and 3.) mentoring from colleagues and superiors. Interestingly, these telecommuters' perceptions were consistent with those of their supervisors and non-telecommuters.

Cooper and Kurland (2002) noted that employees of public firms appeared much less concerned about telecommuters missing employee development opportunities than did private sector employees. Similarly in Hartman, Stoner, and Arora's (1991) study, those telecommuters employed by government agencies reported more satisfaction and higher productivity than those employed by business firms. This was apparently due to the more formal systems governing advancement and skill-development and the greater reliance on formal sources of information (Cooper and Kurland, 2002). Feelings of isolation may also be influenced by employees' need or expectation for advancement opportunities (McCloskey and Igbaria, 1998).

Socially, telecommuters reported missing the informal interaction with colleagues that occurs in the office (Cooper and Kurland, 2002; Treasury Board of Canada Secretariat, 1996). In a fourfactor model of telecommuting withdrawal, "community" defined as "the affect for office social interactions," was primarily associated with reducing telecommuting in a heterogeneous sample of telecommuters across organizations (Fireman, 2000).

Frequency of telecommuting appears to be an important factor influencing isolation: employees in the public sector telecommuting less frequently reported feeling less isolated than those in the private sector telecommuting more frequently (Cooper and Kurland, 2002). Similarly, Pinsonneault and Boisvert's (1996) review concluded that limiting telecommuting frequency and requiring telecommuters to attend company meetings and social events would likely reduce feelings of isolation.

In traditional institutions of higher learning, new faculty members often experience a feeling of isolation when they enter the academy (Cawyer and Friedrich, 1998; Sorcinelli, 1994) and desire 
support from other faculty members (Magnuson, 2002), and more informal communication with administrators (Cawyer and Friedrich, 1998). In an online environment where faculty members were dispersed geographically, isolation from day-to-day contact with virtual colleagues was typical (Yick et al., 2005).

\section{Technology requirements and work group communication}

Effective communication remains a challenge when in a telecommuting context (Kurland and Bailey, 1999; Pinsonneault and Boisvert, 1996), especially when participating in a work group. Bailey and Kurland's (2002) review indicated that few studies had examined the impact of telework on smaller work groups. Researchers, however, have begun to examine how virtual team functions in organizations (Beyerlein, Johnson, and Beyerlein, 2001).

Although it is beyond the scope of this paper to discuss how to use technologies to enhance communication, it is necessary to emphasize that technology requirements play an important role in effective work group communication. In a study examining part-time telecommuters, their supervisors, and non-telecommuters from different organizations, Belanger, Collins, and Cheney (2001) reported that availability of information system technology, availability of communication technologies, and work-related communication patterns within their work groups, positively impacted telecommuters' productivity, performance, and satisfaction. For perceived productivity to be high, there must be a fit between the level of information system technology and the level of communication technology. When the telecommuter occupied a central position in the work group and thus was required to communicate with members frequently, the telecommuter perceived lower levels of productivity and performance.

Through teaching online, academics in online and distance education institutions are constantly exploring how to use information and communication technologies to enhance students' learning effectiveness. They need to consider expanding the use of the same technologies (e.g., Webconferencing tools) to communicate and collaborate with colleagues and staff who are dispersed geographically.

\section{Issues for the Organization}

\section{Remote management}

Despite many positive claims of benefits for the employee, the organization, and the society, telecommuting programmes have not expanded as rapidly as expected. Managerial resistance or reluctance has been the biggest hurdle (Bailey and Kurland, 2002; Karnowski and White, 2002).

Performance Evaluation and Feedback: Performance monitoring and measurement, and managerial control are challenges facing managers of telecommuters (Kurland and Bailey, 1999). Pinsonneault and Boisvert's (1996) concluded in their review that telecommuting requires a change in employee performance from one that is based on process and physical presence, to one that is based on project management and result. Telecommuters should be evaluated in terms of quality, quantity, timeliness, and the extent to which objectives are met. To that end, managers must provide clear descriptions of performance measures, evaluate, and provide feedback regularly. For the employee in Hartman, Stoner, and Arora's (1991) study of telecommuters, satisfaction with how the quality and quantity of work done at home was evaluated was significantly correlated with both telecommuting productivity and telecommuting satisfaction.

As academic work has traditionally been assessed by results, the lack of physical presence may be less of a problem. Nonetheless, clear criteria for assessing employee performance must be 
established, and regular feedback on performance be provided to employees, especially new employees. New faculty members at traditional institutions have reported that institutional expectations (i.e., about tenure and promotion) were unclear (Cawyer and Friedrich, 1998) and that inadequate feedback, recognition, and reward, unrealistic and unclear expectations, and insufficient resources were major sources of stress (Sorcinelli, 1994). In distance and open learning institutions, the expectations for research and services are even less clearly defined. Yick and colleagues (2005) argued that research should be a "core value" promoted by distance and online university because research is critical for the faculty's professional growth and research establishes credibility for the faculty, especially those working with doctoral students.

Managerial Support: To be effective in the telecommuting context, managers must establish a relationship based on confidence and trust with their workers, facilitate good communication between telecommuters and non-telecommuters, ensure adequate resources (e.g., ergonomic furniture and computer equipment at home offices), keep telecommuters informed and active in organizational activities, treat telecommuters like any other employee, and provide training for the whole organizations, including safety and security issues (Pinsonneault and Boisvert, 1996). Research has indicated that satisfaction with the technical and emotional support received from the supervisor while working at home was significantly correlated with telecommuting satisfaction (Hartman, Stoner, and Arora, 1991). Indeed, "discomfort," referring to a lack of supervisor and/ or organizational support, was the primary factor associated with stopping telecommuting in a heterogeneous sample of telecommuters across organizations (Fireman, 2000).

To ensure that all employees have access to the same information, Cooper and Kurland (2002) recommended that information about training opportunities, performance evaluation, career opportunities and advancement, be disseminated through formal channels. Training should be focused on how to maintain open communication between the telecommuter and nontelecommuters, and to stimulate synergy between disparately located employees. Increasingly, organizations are using distance learning and e-learning to train their employees (Burgess and Russell, 2003) and online-mentoring (Ensher, Heun, and Blanchard, 2003). More research to assess the effectiveness of these new initiatives is needed.

Safety and health in home offices are important issues to consider in a progressive telecommuting programme. Rodstein and Watters (2001) recommended that telecommuting policies should ensure minimum ergonomic standards for workstation design are met. Polices should also include clauses related to a hazard-free workspace, employer liability for injuries and illnesses and procedures for reporting them, loss and liability associated with at-home office duties, and insurance coverage of the home office. Even though employers typically retained the right for home inspection in all formal programmes, inspections were seldom conducted (Karnowski and White, 2002).

Like students (Tinto, 1975), new faculty members especially need to be integrated into the institution of higher learning. They desire support from other faculty members, including mentoring (Magnuson, 2002) and faculty orientation programmes (Sorcinelli, 1994). For example, in Cawyer and Friedrich's (1998) study of new faculty members, the number of hours spent in orientation was the single best predictor of a newcomer's satisfaction. In open and distance education institutions where the faculty is dispersed, the institution must provide adequate and effective training and administrative support in the use of technologies to ensure faculty success and satisfaction in online teaching (Yick et al., 2005). Online training and online mentoring could be implemented together with more traditional means of training and mentoring.

Social integration helps to build trusting relationships (Cooper and Kurland, 2002). Creating team synergy, transmitting organizational culture, and promoting a feeling of belonging, remain the 
challenges facing organizations that implement telecommuting programmes (Kurland and Bailey, 1999; Pinsonneault and Boisvert, 1996). To promote a sense of belonging, open and distance education institutions should explore the use of the same tools and technologies used to build communities as we do for our students. In addition, social events contributed significantly to successful socialization within an institution of higher learning (Cawyer and Friedrich, 1998). Events can be held regularly to recognize and celebrate employees' individual and collective achievements.

\section{Recruitment and retention}

Studies of the impacts of telecommuting on faculty recruitment and retention have yet to be located. As proponents for telecommuting claim (Pinsonneault and Boisvert, 1996), telecommuting has the potential to help open and distance education institutions attract academics from a wider geographic area (e.g., outside major urban centres) and from qualified applicants with certain constraints (e.g., disabilities, family responsibilities, lifestyle choices, spousal employment). For employees with disabilities, successful accommodation has been made through telework (West and Anderson, 2005). For couples who are both academics, the option of one partner telecommuting from home while the other partner works for a campus-based institution in the same city can be very desirable. Even though Canadian universities have different policies in hiring couples, not all institutions are willing to accommodate both partners (Eisenkraft, 2004). Telecommuting also has the potential to help retain competent staff (Pinsonneault and Boisvert, 1996). Academics who might otherwise leave a position can remain in their jobs, for example, when their spouse's job requires relocation. Telecommuting may also be an attractive option for those academics in traditional institutions who are interested in online teaching but are not receiving sufficient recognition within their institutions (Yick et al., 2005) and who prefer not to relocate.

On the other hand, the drawbacks of telecommuting discussed earlier could lead to a problem of recruitment and retention in the future. A shortage of university faculty in Canada has been projected to occur beginning in the 1990s when many professors retire (Association of Universities and Colleges of Canada, 1991; Mooney, 1989). As Canadian universities begin to compete for the best academics, open and distance education institutions must strengthen their position in the competition (Heller, Jugdev, Kanuka, and West, 2005) and do their best to retain competent staff. Because many traditional universities are moving toward offering online courses as well (Yick et al., 2005), these institutions can lure away experienced academics who teach online and who feel a sense of isolation telecommuting at their open and distance learning institutions provides. The online teaching experience at an online university would enhance the chance of academics returning to traditional universities should they desire, as expressed by some participants in Yick and colleagues' (2005) study.

Despite the increasing popularity in online education, distance education has continued to be perceived as less desirable in the traditional higher education system (Yick et al., 2005). Some faculty members in their study recognized the current lack of concerted research activity at online universities would hinder their transition to teach at traditional universities. To increase the institution's credibility, faculty members must be encouraged to pursue and engage in scholarly activities through concerted support and resources provided by the administration. In an educational environment where the faculty is dispersed, faculty and university administration may explore the same strategies that they use to communicate with learners (e.g., conferencing tools)

to form faculty support groups (Yick et al., 2005) and to facilitate collaboration and idea exchanges. 


\section{Conclusions}

This paper has discussed several major non-technological issues to be addressed by open and distance education institutions where their core academic staff telecommutes: balance between work and family lives; job productivity and satisfaction; work environment at home; professional and social isolation; remote management; and faculty recruitment and retention. Below is a summary of the potential benefits and drawbacks for telecommuting academics and the opportunities and challenges facing their institution.

\section{Potential benefits for academics}

1. Greater autonomy, more flexibility in work schedule

2. Better balance between personal, family, and work life for some

3. Higher perceived productivity and quality of work

4. Comfortable work environment at home for some

5. Opportunity to take advantage of the geographic location where they reside to conduct research (Yick et al., 2005) and to provide services to those communities

\section{Potential drawbacks for academics}

1. Increased family-work role conflicts for some

2. Lower perceived personal growth and career advancement for some, particularly among new faculty members

3. Professional and social isolation for some; lower collegiality and sense of belonging

4. Over-working because of lack of separation between the work and family domains

5. Inadequate work environment at home for some; occupational and health issues; costs in running the home office

\section{Opportunities for the institution}

1. The ability to recruit employees from a wider geographic area and employees with certain constraints - e.g., disabilities, family responsibilities, spousal employment

2. Better retention of competent staff

3. Other broader strategic planning issues for the institution - e.g., real estates, equipment, and other costs, disaster and emergency management, and usage efficiency of information system proposed in the literature (Pinsonneault and Boisvert, 1996) are not considered in this paper, but are worth examining in future research 
Chuek Fan Ng, Academics Telecommuting in Open and Distance Education Universities

\section{Challenges for the institution}

1. Monitoring and evaluating performance based on results rather than physical presence or visibility

2. Ensuring adequate and appropriate information and telecommunication technologies are equipped in home offices, and effective training and support are provided

3. Ensuring telecommuting academics have an adequate, safe and healthy work environment at home

4. Providing space for research to those academics with specific spatial needs - e.g., laboratories

5. Creating team synergy, transmitting organization culture, and promoting a feeling of belonging to the institution, especially among new faculty members

6. Retaining competent staff and competing with traditional institutions for academics experienced or interested in online teaching as post-secondary institutions anticipate a faculty shortage in the near future.

\section{Future Research Agenda}

This paper has merely scratched the surface of the many issues regarding faculty work conditions and satisfaction in open and distance education institutions. As such, this paper represents a launching pad for further empirical research. Some questions for future research could include:

1. To what extent and in what forms is teleworking implemented in open and distance education institutions around the world?

2. How can technologies be used to better build communities, facilitate collaborations and teamwork, and foster professional development?

3. How can we orient new academics in particular; that is, to learn about job responsibilities and the institutional culture and to develop a sense of belonging to the institution where the faculty is dispersed?

4. How can telecommuting academics maintain a balanced lifestyle when the personal, family, and work boundaries are blurring?

5. What predicts telecommuting success for full-time academics?

6. What are the work experiences of part-time faculty who telecommute?

7. What are the work experiences of academic staff working at remote locations?

8. Kurland and Bailey (1999) argued the satellite office had most of the advantages of homebased telecommuting, but fewer challenges. Despite some interest in working from a satellite office or a neighbourhood centre expressed by Gurstein's (1995) survey respondents, no study that compares home-based telecommuting and satellite offices has yet been located. What are the relative strengths and weaknesses of different forms of teleworking - home-based telecommuting, 
satellite office/ campus, neighbourhood centres for academics in remote locations, and mobile work?

\section{Author Note}

This paper is a revision of a preliminary draft position paper for discussion at the Centre for Psychology at Athabasca University in March of 2003. The author wishes to thank her colleagues of the Centre for Psychology and the Teaching for Good Instructional Fun (T.G.I.F.) committee for their encouragement, and two anonymous reviewers for their insights and constructive comments on the earlier draft of the manuscript.

\section{References}

Alberta Government (1999). Home on the Job: Telecommuting in the Alberta Government. Government of Alberta website. Retrieved September 11, 2006 from: http://www.pao.gov.ab.ca/staff/flexible-work/telecommuting/index.html

Association of Universities and Colleges of Canada (1991). Averting Faculty Shortages: A discussion paper on the Canadian academic labour market in the 1990s. Ottawa, ON.

Bailey, D. E., and Kurland, N. B. (2002). A review of Telework Research: Findings, new directions, and lessons for the study of modern work. Journal of Organizational Behavior 23(4), 383-400.

Bean, J., and Metzner, B. (1985). A conceptual model of nontraditional undergraduate student attrition. Review of Educational Research 55, 485-650.

Belanger, F., Collins, R. W., and Cheney, P. H. (2001). Technology requirements and work group communication for telecommuters. Information Systems Research 12(2), 155-176.

Beyerlein, M. M., Johnson, D. A., and Beyerlein, S. T. (Eds.) (2001). Virtual Teams. Advances in Interdisciplinary Studies of Work Teams 8, 1-258.

Burgess, J. R. D., and Russell, J. E. A. (2003). The effectiveness of distance learning initiatives in organizations. Journal of Vocational Behavior 63(2), 289-303.

Cooper, C. D., and Kurland, N. B. (2002). Telecommuting, professional isolation, and employee development in public and private organizations. Journal of Organizational Behavior 23(4), 511-532.

Cawyer, C. S., and Friedrich, G. W. (1998). Organizational Socialization: Processes for new communication faculty. Communication Education 47(3), 234-245.

Duxbury, L., Higgins, C., and Neufeld, D. (1998). Telework and the balance between work and family? Is telework part of the problem or part of the solution? In M. Igbaria and M. Tan (Eds.) The Virtual Workplace (p. 218-255). Hershey, PA.: Idea Group Publishing.

Eisenkraft, H. (2004). Academic couples. University Affairs, November. Retrieved August 31, 2006 from: http://www.universityaffairs.ca/issues/2004/november/_print/academic couples.html 
Ellison, N. B. (1999). Social Impacts: New perspectives on telework. Social Science Computer Review 17(3), 338-356.

Ensher, E. A., Heun, C., and Blanchard, A. (2003). Online Mentoring and Computer-Mediated Communication: New directions in research. Journal of Vocational Behavior 63(2), 264288.

Fireman, S. M. (2000). A Model of Telecommuting Withdrawal: Employee perceptions predicting the reduction or stopping of telework. Dissertation Abstracts International. Section A: Humanities and Social Sciences 60(11-A), 4084.

Gappa, J. M., Austin, A. E., and Trice, A. G. (2005). Rethinking academic work and workplaces. Change: The Magazine of Higher Learning 37(6), 32-39.

Golden, T. D., and Veiga, J. F. (2005). The Impact of Extent of Telecommuting on Job Satisfaction: Resolving inconsistent findings. Journal of Management 31(2), 301-318.

Gurstein, P. (1995). Planning for Telework and Home-based Employment: A Canadian survey on integrating work into residential environments. Ottawa, ON.: Canada Mortgage and Housing Corporation.

Guthrie, R., Olson, P. C., and Schaeffer, D. M. (1998). The professor as teleworker. In M. Igbaria and M. Tan (Eds.) The Virtual Workplace (p. 288-300). Hershey, PA: Idea Group Publishing.

Hartman, R. I., Stoner, C. R., and Arora, R. (1991). An investigation of selected variables affecting telecommuting productivity and satisfaction. Journal of Business and Psychology 6(2), 207-225.

Heller, R., Jugdev, K, Kanuka, H., and West D. (2005). Investing in Our Faculty. Internal report. Athabasca, AB.: Athabasca University.

Hill, E. J., Ferris, M., and Martinson, V. (2003). Does it matter where you work? A comparison of how three work venues (traditional office, virtual office and home office) influence aspects of work and personal / family life. Journal of Vocational Behavior 63(2), 220241.

Karnowski, S., and White, B. J. (2002). The role of facility managers in the diffusion of organizational telecommuting. Environment and Behavior 34(3), 322-334.

Irani, T., Telg, R., Scherler, C., and Harrington, M. (2003). Personality type and its relationship to distance education students' course perceptions and performance. The Quarterly Review of Distance Education 4(4), 445-453.

Kurland, N. B., and Bailey, D. E. (1999). Telework: The advantages and challenges of working here, there, anywhere, and anytime. Organizational Dynamics 28(2), 53-68.

McCloskey, D. W., and Igbaria, M. (1998). A review of the empirical research on telecommuting and directions for future research. In M. Igbaria and M. Tan (Eds.) The Virtual Workplace (p. 338-358). Hershey, PA.: Idea Group Publishing. 
Magnuson, S. (2002). New Assistant Professors of Counselor Education: Their 1st year. Counselor Education and Supervision 41(4), 306-320.

Mooney, C. J. (1989). Uncertainty is rampant as colleges begin to brace for faculty shortage expected to begin in 1990's. The Chronicle of Higher Education 35, A14.

Moore, J. C. (2002). Elements of Quality. The Sloan-C framework. Learning Abstracts 5(12), 13. Retrieved July 19, 2006 from: http://www.league.org/publication/abstracts/learning/lelabs0212.html

Mullens, A. (2001). The Sessional Dilemma. University Affairs, May. Retrieved August 31, 2006 from: http://www.universityaffairs.ca/issues/2001/may/sessional2.pdf

Nilles, J. M. (1975). Telecommunications and organizational decentralization. IEEE Transactions on Communications 23, 1142-1147.

Olson, M. H., and Primps, S. B. (1984). Working at Home with Computers: Work and nonwork issues. Journal of Social Issues 40(3), 97-112.

Pinsonneault, A., and Boisvert, M. (2001). The Impacts of Telecommuting on Organizations and Individuals: A review of the literature. In Johnson, N. J. (Ed.)Telecommuting and Virtual Offices: Issues and opportunities (p. 163-185). Hershey, PA.: Idea Group Publishing.

Rodstein, J. T., and Watters, K. S. (2001). Safety and health in the virtual office. In Johnson, N. J. (Ed.) Telecommuting and Virtual Offices: Issues and opportunities (p. 213-230). Hershey, PA.: Idea Group Publishing.

Rovai, A. P. (2003). In search of higher persistence rates in distance education online programs. Internet and Higher Education 6(1), 1-16.

Rovai, A. P., Wighting, M. J., and Liu, J. (2005). School Climate: Sense of classroom and school communities in online and on-campus higher education courses. The Quarterly Review of Distance Education 6(4), 361-374.

Ryan, M., Carlton, K. H., and Ali, N. S. (2004). Reflections on the role of faculty in distance learning and changing pedagogies. Nursing Education Perspectives 25(2), 73-80.

Shea, P., Pickett, A., and Li, C. S. (2005). Increasing Access to Higher Education: A study of the diffusion of online teaching among 913 college faculty. International Review of Research in Open and Distance Learning 6(2). Retrieved August 29, 2006 from: http://www.irrodl.org/index.php/irrodl/article/view/238/493

Sorcinelli, M. D. (1994). Effective approaches to new faculty development. Journal of Counseling and Development 72(5), 474-479.

Tinto, V. (1975). Dropout from Higher Education: Atheoretical synthesis of recent research. Review of Educational Research 45(1), 89-125.

Treasury Board of Canada Secretariat (1996). Evaluation of Telework Pilot Policy: Findings. Ottawa: Minister of Supply and Services Canada. 
West, M. D., and Anderson, J. (2005). Telework and Employees with Disabilities: Accommodation and funding options. Journal of Vocational Rehabilitation 23(2), 115122.

Wheeler, S. (2002). Student perceptions of learning support in distance education. The Quarterly Review of Distance Education 3(4), 419-429.

Workman, J. J., and Stenard, R. A. (1996). Student support services for distance learners. DEOSNEWS 6(3). Retrieved August 10, 2006, from: http://www.ed.psu.edu/acsde/deos/deosnews/deosnews6_3.asp

Yick, A. G., Patrick, P., and Costin, A. (2005). Navigating Distance and Traditional Higher Education: Online faculty experiences. The International Review of Research in Open and Distance Learning 6(2). Retrieved July 19, 2006 from: http://www.irrodl.org/index.php/irrodl/article/viewArticle/235/320

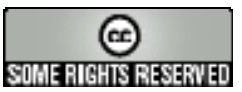

